7. Reprod. Fert. (1969) 20, 541-543

\title{
THE FIXATION OF CARBON DIOXIDE BY THE EIGHT-CELL MOUSE EMBRYO
}

\author{
R. G. WALES, P. QUINN AND R. N. MURDOCH \\ Department of Veterinary Physiology, University of Sydney, \\ Sydney 2006, Australia
}

(Received 18th Fuly 1969)

Mouse embryos require the presence of a bicarbonate buffer system for their development in vitro. The energy requirements for oocyte maturation and early zygote development prompted Biggers, Whittingham \& Donahue (1967) to suggest that the fixation of carbon dioxide may play a rôle in the energy metabolism of the early embryo. The present study was undertaken in an attempt to demonstrate this reaction in the eight-cell mouse embryo.

For each experiment, 400 eight-cell mouse embryos were flushed from the reproductive tracts of superovulated female albino mice. The basic medium was Krebs-Ringer bicarbonate containing $25 \mathrm{~mm}$-sodium DL lactate, $0.25 \mathrm{~mm}$ sodium pyruvate, $0.01 \mathrm{~mm}$-sodium ketoglutarate, $0.01 \mathrm{~mm}$-sodium malate, $0.01 \mathrm{~mm}$-sodium citrate, $1 \mathrm{mg} / \mathrm{ml}$ bovine serum albumin, $60 \mu \mathrm{g} / \mathrm{ml}$ penicillin, $50 \mu \mathrm{g} / \mathrm{ml}$ streptomycin. After washing by transfer through two changes $(2 \mathrm{ml}$ each) of this medium, the embryos were cultured in $20 \mu \mathrm{l}$ droplets of medium (forty embryos/drop) containing $\mathrm{NaH}^{14} \mathrm{CO}_{3}$ (specific activity $10 \mathrm{mCi} / \mathrm{m}$-mole) in a 35-mm diameter plastic culture dish (Falcon Plastics) containing $3 \mathrm{ml}$ light paraffin oil. The culture dish was cemented in a glass petri dish of approximately $27-\mathrm{ml}$ volume. Sufficient radio-active bicarbonate, of the same specific activity as that in the culture medium, was pipetted into one side of the glass petri dish to produce a $5 \% \mathrm{CO}_{2}$ atmosphere in the dish after acidification and $0.2 \mathrm{ml}$ of $6 \mathrm{~N}_{-} \mathrm{H}_{2} \mathrm{SO}_{4}$ was pipetted into the opposite side of the dish. The lid of the petri dish was sealed and the dish tipped slightly to mix the acid with the bicarbonate to release carbon dioxide.

After a 24-hr period of culture at $37^{\circ} \mathrm{C}$, all the developed embryos were separated from the medium as previously described (Wales \& Biggers, 1968). The medium was also collected and both embryos and medium were acidified with $0 \cdot 1 \mathrm{ml} 2 \mathrm{~N}-\mathrm{H}_{2} \mathrm{SO}_{4}$ and placed in a closed container containing $2 \mathrm{~N}-\mathrm{NaOH}$ for $24 \mathrm{hr}$ to absorb liberated carbon dioxide. After neutralization with $\mathrm{NaOH}$, a small aliquot was taken for radio-assay and the remainder was fractionated to determine the amount of label in the acid-soluble, protein and lipid fractions as described below.

A $50-\mu 1$ sample of sheep serum was added to both embryos and medium to act as carrier for the labelled compounds. Protein was precipitated with $2.5 \%$ perchloric acid. After washing the precipitate four times with $20 \%$ trichloroacetic acid, it was extracted with chloroform-ether $(1: 1)$. The acid-soluble 
fraction was fractionated into basic, neutral and acidic compounds by passing it through a column of cation exchange resin followed by an anion exchange resin. Full details of the method will be published elsewhere.

In a preliminary experiment, 400 eight-cell embryos which had been inactivated by incubation for $30 \mathrm{~min}$ in phosphate-buffered saline containing $10 \%$ formalin, were kept for $24 \mathrm{hr}$ in radio-active bicarbonate in the same manner as the living embryos. After collection and acidification, a total of 7 counts/min was found in these dead embryos. This compares with 16,000 counts/min when the same number of live embryos was cultured. In addition, the medium in which the formalin-killed embryos were kept contained the same number of counts after acidification and extraction as a control sample of unincubated medium similarly treated. Both contained $0.005 \%$ of the added isotope and correction was made for these background counts in calculating the net incorporation of isotope in the following experiments.

Table 1 shows the results of the experiments to measure the incorporation of carbon from bicarbonate by eight-cell embryos during $24 \mathrm{hr}$ in culture. In the three experiments, an average of $94 \%$ of embryos developed into morulae or

TABLE 1

INCORPORATION OF CARBON FROM SODIUM BICARBONATE BY EIGHT-CELL MOUSE EMBRYOS DURING 24 HR IN GULTURE

\begin{tabular}{c|c|cccc|c|c}
\hline \multirow{3}{*}{$\begin{array}{c}\text { Fraction } \\
\text { assayed }\end{array}$} & \multirow{3}{*}{$\begin{array}{c}\text { Replicate } \\
\text { no. }\end{array}$} & \multicolumn{5}{|c}{ Carbon incorporated $\left(\mu \mathrm{g}\right.$ atoms $\times 10^{-8} /$ embryo) } \\
\cline { 2 - 8 } & Total & Acid soluble compounds & Acidic & Basic & Neutral & Protein & fipid \\
fraction & fraction \\
\hline Embryos & 1 & 323 & 197 & 113 & 13 & 93 & 5 \\
& 2 & 313 & 172 & 128 & 13 & 70 & 6 \\
& 3 & 426 & 251 & 162 & 17 & 111 & 11 \\
& Mean & 354 & 207 & 134 & 14 & 91 & 7 \\
\hline Medium & 1 & 175 & 114 & 35 & 26 & 0 & 0 \\
& 2 & 252 & 164 & 63 & 25 & 0 & 0 \\
& 3 & 249 & 154 & 67 & 30 & 0 & 0 \\
& Mean & 225 & 144 & 55 & 27 & 0 & 0 \\
\hline
\end{tabular}

early blastocysts. Most of the isotope incorporated into the embryos was present in the acid-soluble fraction. Of this, $60 \%$ was incorporated into acidic compounds, $38 \%$ into basic compounds and there was a minor labelling of the neutral fraction. In addition, there was substantial incorporation into the protein of the embryo and a minor labelling of lipids.

Incorporation into the acid-soluble fraction of the medium was also substantial and as the major portion of the label was present in acidic compounds, an aliquot was applied to a column of silicic acid and the carboxylic acids eluted with hexane-butanol mixtures (O'Shea \& Wales, 1968). Approximately $50 \%$ of the labelled acidic compounds were eluted in the peak corresponding to lactate, and other smaller peaks corresponding to acetate, malate, ketoglutarate and citrate were also seen. Probably, this accumulation of radioactive products in the medium only reflects the leakage of certain metabolic 
intermediates from the embryo during culture and their trapping in the substrate pool of the medium. When aliquots of the acid-soluble fraction of embryos were chromatographed in a similar fashion, only a small proportion of the isotope applied was eluted and no radio-active peak corresponding to lactate was found.

The results demonstrate a substantial gain in carbon by the embryo through fixation of carbon dioxide from the surroundings. A similar amount of carbonone of pyruvate is accumulated in the embryo during this period when 0.5 mM-pyruvate is present as sole substrate (R. G. Wales \& D. G. Whittingham, unpublished observations). This suggests that the main route of entry for carbon-one of pyruvate into the carbon pool of the embryo is by the conversion of pyruvate to oxaloacetate. Thus, in addition to maintaining a suitable hydrogen ion concentration in the incubation medium, bicarbonate buffer supplies the carbon for this conversion. However, bicarbonate may play some further function in the developing embryo as no development of eight-cell embryos to blastocysts occurred when oxaloacetate was substituted for pyruvate in the medium and the zwitterionic buffer $\mathcal{N}$-2-hydroxyethylpiperazine- $\mathcal{N}^{\prime}$-2ethanesulphonic acid was used.

The authors are grateful to Professor C. W. Emmens for his interest and criticism. The work was aided by a grant from the Australian Research Grants Committee. One of us (P.Q.) was supported by an Australian Wool Board Post-graduate studentship.

\section{REFERENCES}

Biggers, J. D., Whittingham, D. G. \& Donahue, R. P. (1967) The pattern of energy metabolism in the mouse oocyte and zygote. Proc. natn. Acad. Sci. U.S.A. 58, 560 .

O'SheA, T. \& Wales, R. G. (1968) Metabolism of $\left[1-{ }^{14} \mathrm{C}\right]$ sodium lactate and $\left[2-{ }^{14} \mathrm{C}\right]$ sodium lactate by ram spermatozoa. F. Reprod. Fert. 15, 337.

Wales, R. G. \& Biggers, J. D. (1968) The permeability of two- and eight-cell mouse embryos to L-malic acid. F. Reprod. Fert. 15, 103. 